\title{
Feminism < > Dialogic Interaction < > Research Miriam Cooley
}

I am engaged in a descriptive, qualitative study which focuses on the learning experiences of women Visual Arts students in the Faculty of Fine Arts, Concordia University. I am conducting loosely structured, video taped interviews with forty undergraduate women. 1 am asking how these women understand their lives and artistic production and what meanings they develop or assign to the events of their school day. I am looking at their art work and I want to hear how they describe and reflect upon the representation of their ideas in their work. I expect that this approach will provide insights into the ways that women think about their art learning/art making processes and how they respond to the instruction that they receive.

Over the past year I have spent a great deal of time considering the issues I find to be inherent to the methods and practices of ethnographic research. In this paper I would like to review some of the theoretical perspectives that have informed my thinking about this project. In particular, I would like to consider some concerns drawn from my reading of feminist theory as it relates to issues of representation and the concepts of Otherness and dialogue. I am currently preoccupied with questions about the impact of these issues with respect to the methodology(s) that I employ as I proceed with this project.

Firstly, my MA thesis was a personal point of view investigation of video, from the perspective of the proposals of the dialogic nature of aesthetic response as proposed by Professor Stan Horner. The concept of a dialogic relationship between the artist/viewer and the artistic text and between teacher and student (and by analogy - in my present case, between research interviewer and respondent) is integral to Horner's concept of aesthetic response. He talks about a process of engagement with the work of art into which one journeys with one's whole self,

into a dream time-space, engaging the 'active imagination' [...] into a world of analogical flow, of associations, puns and put-ons [open to the meaning(s) that] emerges at the intersection where expectation schema of a viewer's desire meet with those of the author's desire.

(Horner 1989: 8)

The intangibility of these ideas provoked my desire to pursue further the question of the dynamics of aesthetic response, dialogic interactions (artist/text, viewer/text, self/other, teacher/student) and the construction of meaning within that process. 
My long standing interest in the women's learning and artistic practice was, of course, informed by the wealth of critical and theoretical work produced by feminist writers, artists and educators. Psychoanalytic theory has very productively informed feminist literary and art criticism (Laura Mulvey, Kate Linker, Teresa de Lauretis, et. al.) particularly in that Freudian psychoanalysis has situated gender as a fundamental player in creative experience. While I have found psychoanalytic theory to be a problematic companion to feminism, I have none the less gleaned some valuable ideas.

A reference to Julia Krestiva in Horner's writing prompted me to pursue an exploration of her concept of the semiotic; a pre-oedipal space, seen as a site underlying the evolution of human creative processes. She describes the semiotic as a kind of pre-signifying energy, best understood as a trace, a precursory sign or imprint. It is the site of non-signifying, anarchic, undisciplined energies that animate the impulsive rhythms of the infant's body and which predates both conscious corporal control and the possibility of the distinction between subject and object. It is unspeakable; unimaginable; and necessarily feminine.

Those unfocused energies articulate the chora; a pre-imaginary, pre-linguistic rhythm space, anterior to the distinction between real and symbolic; a function of the infant's unmediated and illusionary relation with the body of the mother. The point of interest to me here is that "the symbiotic space shared by the mother's and child's indistinguishable bodies." Grosz (1989: 43) posits the maternal body as the site of the unspoken foundation of signification and source of jouissance. * This Symbiotic space must necessarily be "called to order" through the Oedipal crisis, Mirror phase and discovery of castration so that the symbolic order can be realized through language.

In Kristeva's scheme of things the semiotic and the symbolic together are the impetus, through their dialogic interaction, for the construction of the subject, the production of discourse, and the regulation of social relations. In spite of the apparent dominance of the symbolic order its security is never assured since dynamic semiotic energies continue as a perpetual threat. Her thesis is that artistic language functions in the thetic moment of primal repression and that distinctive avant-garde texts, and certain visual works reveal otherwise repressed traces of the semiotic energies which fuel poetic language.

In visual works, such as those of the Italian artist Bellini, she discerned the semiotic at play in the representation of the space between, and attitude of the mother and child, but most particularly in the luminosity of the sky and the diffusion of light within the pictorial space. (Kristeva 1980: 237)

A problem arises here in that, since she adheres to Freudian/ Lacanian psychoanalytic theory, the subject/agent/artist who eventually may have access to that luminous site is necessarily masculine. The feminine is 
cast inevitably as the Other, lacking desire and hence lacking agency and creative possibility. Kristeva asserts that since there is no unified female subjectivity, the category of "Woman" does not exist and hence the impossibility of a feminine identity, even as maternal. Such a position on female subjectivity renders gender invisible and precludes any discussion of difference or sexuality, or of the socio-political con-sequences of how we live as gendered being. As Trinh T. Minh-ha says, "there is simply no point outside of Kristeva's 'sexual identities' from which to take up a position" (Trinh T. Minh-ha 1989: 104). It is not surprising that theoretical positions such as Kristeva's have been seen by many as an obscuration of female lived experience in favour of monolithic theory making in the 'male' camp of academia. (Christian 1987)

Obviously, one is not bound to this analysis and there are notable examples of feminist reassertions of sexual difference, not as an essentialist category but as a necessary recognition of female lived experience. Jessica Benjamin draws upon Winnicottian (1971) rethinking of Freudian analysis as she undertakes a reassessment of the psychic development of autonomous human subjects. She proposes a representation of female desire and agency realized through transition into inter-subjectivity rather than through radical individuation. In order to reposition the polarized masculine/feminine duality as a dynamic tension of difference; to find an alternative mode of structuring the psyche that acknowledges female will, agency and desire; and to make it possible for women to engage in authentic representational practices.

Benjamin proposes the concept of "the intersubjective mode of desire [which] has its counterpart in spacial rather than symbolic representation." Intersubjectivity "happens between individuals, and within the individual with others, rather than within the individual psyche" as "part of a continuum that includes the space between the I and the You." (Benjamin 1986: 94-5) Winnicott's work is very influential in this notion of transition and the comprehension of the space between the Self and the Other as the site of active, dialogic interaction fostering cultural representations.

The work of Russian literary theorist Mikhail Bakhtin (which I came to through references bout his influence on Kristeva's work) provided further insights into the actualizing of the dialogic process both within the literary text (the novel) and in human interactions. For Bakhtin, 'the Other' exists with autonomous integrity, outside one's self, standing over and against the self as an object, in space and in time. What I find exciting about Bakhtin is the expansive, inclusive and optimistic possibilities for learning and knowing that he opens up. With reference to text he specifies an "elastic environment" existing between words in a "process of living interaction" that sets up a dynamic and complex, "dialogically agitated and tension filled" context. (Bakhtin in Holquist 1991: 103) He proposed a concept of human dialogue as founded on sympathetic understanding, a concept which he saw as, 
...not a mirroring, but a fundamentally and essentially new valuation ... [which]... recreates the whole inner person in aesthetically loving categories for a new existence in a new dimension of the world.

(Bakhtin in Holquist 1991: 103)

So what is the point of all this? While there are interesting analogies to be drawn from the notion of the semiotic in relationship to Otherness and to dialogic interaction, what difference does it all make to women as artists or students or teachers or researchers?

On the textual level, i.e. works of art, it remains to be seen if there is evidence of the semiotic jouissance rippling just beneath the surface of the student's work, or blirting out inadvertently in their speech. These ideas are certainly provocative points of reflection which will play a part in the way / view and interpret the data.

My present concern is to engage in a research process that will genuinely extend respect for the participation of the students, and thus I fell, will have the potential to bring forward sincere and forthright responses. The recent work of Lyn Brown \& Carol Gilligan, (1992) which I choose to consider as feminist research exemplifying what Elliot Eisner refers to as connoisseurship, (Eisner 1991) made me realize the significance of my feminism/dilogical inter-action preoccupations in at least one very important regard. Brown \& Gilligan's discussion of their experience as they studied girls' psychological development made me exceedingly mindful that within the research process itself there must be consistent respect for the dialogic relationship inherent to that process. They were forced to re-evaluate their role and responsibility as researchers if they expected to establish a comfortable relationship of trust with the girls they were interviewing. They adopted an open ended format that gave the interviewee a key role in directing the conversation and involved the interviewer in the role of active listening and responding, not just asking and documenting. It became imperative that, "we ask not only who is speaking but who is listening" (Brown \& Gilligan 1992: 22-30) Thus, as feminist researchers and as connoisseurs they recast the entire process of researching as a relational practice in which,

.....we attend to the relational dimensions of our listening, speaking, taking in, interpreting, and writing about the words and silences, the stories and narratives of other people.

(Brown \& Gilligan 1992: 22)

The first practical consequence for me was to realize that who I chose to interview was of serious importance. There was no reason why a total stranger should volunteer to even talk with me much less discuss the issues that are important to this project, regardless of how engaged and sincere I might be. It became apparent to me that the only students who I could presume to even ask to participate would be students who I have taught myself, who know me, and with whom I have established a positive

Marilyn Zurmuehlen's Working Papers in Art Education 1993 
relationship. My preliminary discussions of the project with this group of students has been received with great interest and enthusiasm. I expect to begin the interviews over the summer and I look forward to the experience with great anticipation.

\section{Footnote}

* Jouissance: sexual pleasure and bliss, an intense rapturous pleasure which women know. Jouissance carries notions of luidity, diffusion and duration.

\section{References}

Benjamin, J. (1986). A desire of one's own: Psychoanalytic feminism and intersubjective space. In T. de Lauretis (Ed.), Feminist Studies/Critical Studies (pp. 78-101). Bloomington: Indiana University Press.

Brown, L. M., \& Gilligan, C. (1992). Meeting at the crossroads: Women's psychology and girl's development. Cambridge, MA: Harvard University Press.

Christian, B. (1987). The race for theory. Cultural Critique: the Nature and Context of Minority Discourse, \#6 (Spring), 51-63.

de Lauretis, T. (1984). Alice doesn't: Feminism, semiotics, cinema. Bloomington: Indiana University Press.

Eisner, E. W. (1991). The enlightened eye: Qualitative inquiry and the enhancement of educational practice. New York: Macmillan Publishing Company.

Grosz, E. (1989). Sexual subversions: Three French feminists. Sydney: Allen \& Unwin.

Holquist, M. \& Liapunov, V. (Eds.). (1991). Art and answerability: Early philosophical essays by M. M. Bakhtin (V. Liapunov \& K. Brostrom, Trans.). Austin: University of Texas Press.

Horner, S. (1989). Responding to art; 2 C \& not 2B: That is not a question. Unpublished paper.

Kristeva, Julia. (1980). Desire in language: A semiotic approach to literature and art (L. Roudiez, Ed.) (T. Gora, A. Jardine \& L. Roudiez, Trans.). New York: Columbia University Press.

Linker, K. (1984). Representation and sexuality. In B. Wallis (Ed.), Art after modernism: Rethinking representation (pp. 391-416). New York: The New Museum of Contemporary Art. 
Mulvey, L. (1984). Visual pleasure and the narrative cinema. In B. Wallis (Ed.), Art after modernism: Rethinking representation (pp. 361-374). New York: The New Museum of Contemporary Art.

Trinh T. M. (1989). Woman, native, other. Bloomington: Indiana University Press.

Winnicott, D. W. (1971). Playing and reality. London: Tavistock Publications, Ltd. 